\title{
GGU's expedition in the Disko Bugt area, 1988
}

Feiko Kalsbeek

The aim of GGU's expeditions in the Disko Bugt area 1988-1992 is threefold. Firstly, to enhance our general geological knowledge of the area which has previously only been studied in very limited detail (see Escher \& Burri, 1967; Kalsbeek et al., 1988; Knudsen et al., 1988). Secondly, to study the mineral potential of the region with the main emphasis on the supracrustal rocks north-east of Disko Bugt, where previous reconnaissance studies by Kryolitselskabet $\emptyset$ resund $\mathrm{A} / \mathrm{S}$ and GGU have located mineral showings with $\mathrm{Cu}, \mathrm{Zn}, \mathrm{Au}$ and $\mathrm{Ag}$ in addition to a number of geochemical anomalies (Steenfelt, 1987, 1988; Appel \& Knudsen, 1988; Knudsen et al., 1988). Thirdly, to investigate the Cretaceous-Tertiary sediments and basalts on Disko and Nûgssuaq (Henderson et al., 1976; Clarke \& Pedersen, 1976) to obtain more information on the development of the onshore part of the West Greenland basin, which is important for a better insight into the hydrocarbon potential of this basin.

The very diverse goals of the expedition necessitated a close cooperation between different departments within GGU. Moreover, cooperation with the Geological Institute, University of Copenhagen, is also a major asset in pursuing these goals. In total, twelve teams of geologists (see below) took part in the expedition. Four of these worked in the Cretaceous-Tertiary basin and eight in the Precambrian terrain north-east of Disko Bugt. The base camp of the expedition was situated at Atâ, an abandoned settlement on the east coast of Arveprinsen Ejland (fig. 1). The base staff consisted of Feiko Kalsbeek (expedition leader), Palle Bay and Jørgen Lau (quartermasters), and Karen Henriksen (cook). The expedition was served by a Bell 206 B Jet Ranger helicopter, chartered from Greenlandair Charter A/S. Urs Stoller was the pilot, and a rota of mechanics carried out the maintenance of the helicopter. GGU's cutter $J$. F. Johnstrup, with Andreas Viðstein as skipper, also served the expedition.

\section{Precambrian rocks east and north-east of Disko Bugt}

The area east and north-east of Disko Bugt consists mainly of Archaean granitoids and gneisses (Kalsbeek et al., 1988). Regional reconnaissance in this area and in the eastern part of Nûgssuaq was initiated by Agnete Steenfelt and Adam Garde. One important finding was that the easternmost part of Nuggssuaq contains major outcrops of anorthosite and associated rocks (Garde \& Steenfelt, 1989). This team also continued the regional geochemical mapping and exploration programme started by Steenfelt $(1987,1988)$.

A large area around Atâ consists of Archaean granitoid rocks, the 'Atâ Granite' (Escher \& Burri, 1967; Kalsbeek et al., 1988; see also Knudsen et al., 1988). These rocks and their relations to the surrounding gneisses were further studied by Lilian Skjernaa (University of Copenhagen) and by Christian Knudsen and Mogens Marker. Further evidence was found that some of the gneisses in the region were formed by deformation of Atâ granite, whereas other gneisses are older than the granite (Knudsen et al., 1988). The basement is cut locally by major gabbroic dykes dated at $c .1650 \mathrm{Ma}$ (Kalsbeek \& Taylor, 1986); local ultramafic dykes of lamprophyric affinity were discovered this summer (Marker \& Knudsen, 1989).

On Arveprinsen Ejland and near Eqe (fig. 1) the Atâ granite intrudes into amphibolites, greenschists and minor metasediments which, therefore, must be of Archaean age. In the area east of Eqe these rocks are associated with acid metavolcanics (Knudsen et al., 1988). All these rocks are strongly deformed and, although only a small part of the sequence is cut by Atâ granite, we have the impression that they may all prove to be of Archaean age. The supracrustal rocks of Arveprinsen Ejland and in the Eqe area contain sulphide occurrences locally with up to $12 \mathrm{ppm}$ gold (Knudsen $e t$ $a l .$, 1988). The supracrustal rocks east of Eqe were studied in detail by Christian Knudsen and Mogens Marker, and those on Arveprinsen Ejland by Hans Kristian Schønwandt and Brian Marshall (University of Technology, Sydney). The supracrustal rocks on Arveprinsen Ejland contain several interesting mineral occurences, one of which, the 'Anderson showing' (see Knudsen et al., 1988), was studied in detail by Schønwandt and Marshall.

The area north-east of Disko Bugt contains another sequence of supracrustal rocks, mainly dark siltstones 


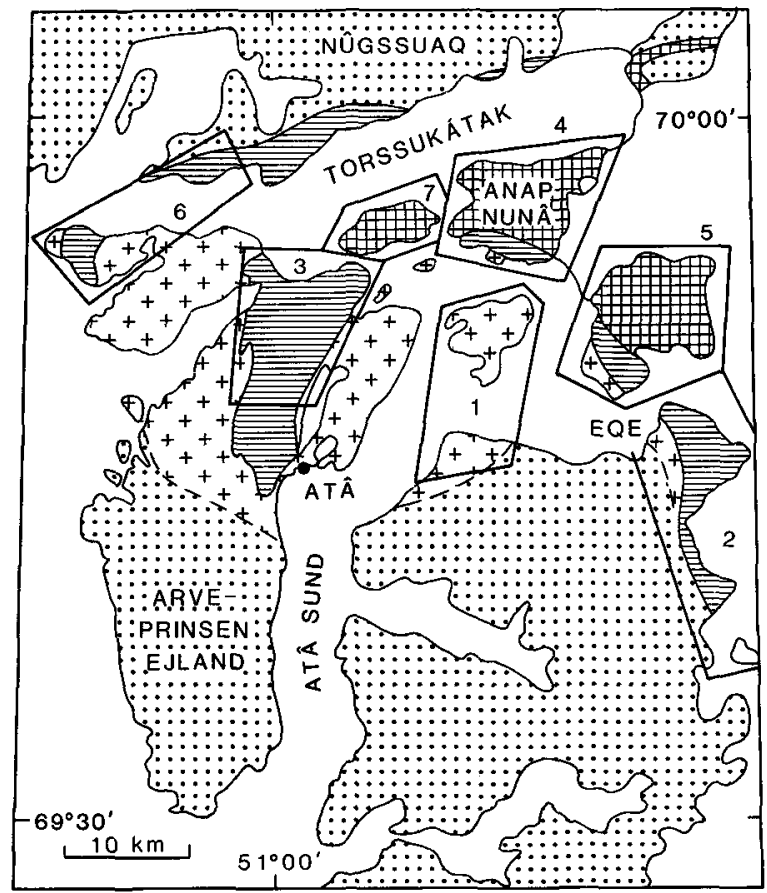

Fig. 1. Preliminary geological sketch of the area north-east of Disko Bugt with localities named in the text. Stipple: regional gneisses (Archaean). Crosses: Atâ granite (Archaean). Horizontal ruling: Archaean supracrustal rocks. Cross-hatched: Proterozoic supracrustal rocks (Anap nunâ group). Study areas are as follows. 1: Lilian Skjernaa, 2: Christian Knudsen \& Mogens Marker, 3: Hans Kristian Schønwandt \& Brian Marshall, 4: Heidi Sjølin Thomsen \& Johan Andersen, 5: Anna Toft \& Hans Peter Birk Hansen, 6: Henrik Rasmussen \& Lars Frimodt Pedersen, 7: Feiko Kalsbeek.

and quartzitic rocks, the 'Anap nunâ group', with local gabbroic intrusions (Escher \& Burri, 1967). The rocks of the Anap nunâ group are folded into relatively simple structures, with local faults. Penetrative deformation is generally insignificant and sedimentary structures are often well preserved. The rocks are of a very low metamorphic grade. The age of these rocks is not well known, but isotope evidence very strongly suggests that they are early Proterozoic, i.e. significantly younger than the supracrustal rocks cut by Atâ granitoids (Kalsbeek et al., 1988). The contact between the Anap nunâ supracrustals and the supracrustal sequence in the Eqe area has not yet been located with certainty. However, mapping in the strongly deformed (Archaean?) supracrustal rocks suggests there may be an angular unconformity between the two units. Further mapping in 1989 is necessary to confirm this suspicion.

The Anap nunâ group and parts of the strongly deformed supracrustal rocks which borders on it were studied and mapped by two teams of students from the Geological Institute, University of Copenhagen: Heidi Sjølin Thomsen and Johan Andersen, and Anna Toft and Hans Peter Birk Hansen. A third team of students, Henrik Rasmussen and Lars Frimodt Pedersen, mapped supracrustal rocks north and south of Torssukatak (fig. 1). These rocks are of a higher metamorphic grade and strongly deformed, and it is uncertain whether any of them belong to the Anap nunâ group.

Leif Thorning and Egon Hansen carried out geophysical work. They measured magnetic susceptibility and gravity at 212 sites in the northern part of Arveprinsen Ejland (fig. 1) and adjacent areas to prepare a Bouguer anomaly map (Thorning, 1989). Detailed magnetic and electromagnetic measurements were also made around the 'Anderson showing' (see above).

\section{The Cretaceous-Tertiary basin on Disko and Nûgssuaq}

The boundary between the Precambrian basement and the Cretaceous-Tertiary basin runs through the eastern part of Disko Bugt and through Nûgssuaq, where the two units are separated by a system of faults. The geology of the border zone was studied by Pulvertaft (1989).

Studies of the Cretaceous and Tertiary sediments were undertaken by Gunver Krarup Pedersen and Birgitte Ferré Rasmussen and by Helle Harvig Midtgaard and Torben Olsen, while the Tertiary basalts were studied by Lotte Melchior Larsen and Asger Ken Pedersen. The investigations in the Cretaceous-Tertiary basin are a continuation of earlier work (see Pedersen \& Jeppesen, 1988 and Larsen \& Pedersen, 1988). Brief reports on the results of this summer's work appear elsewhere in this volume (Pedersen \& Rasmussen, 1989; Midtgaard \& Olsen, 1989; Larsen \& Pedersen, 1989).

Acknowledgements. On behalf of all expedition members I wish to express our gratitude to our helicopter pilot Urs Stoller; without his skill and cooperation the expedition would not have been as successful as it was. Participation of Lilian Skjernaa, Mogens Marker, Anna Toft and Gunver Krarup Pedersen was supported by the Danish Natural Science Research Council; Christian Knudsen was supported by a grant from the Carlsberg Foundation, and Hans Peter Birk Hansen was partly supported by the University of Copenhagen.

\section{References}

Appel, P. W. U. \& Knudsen, C. 1988: Stream sediment sampling in the Atâ area central West Greenland. Rapp. Grønlands geol. Unders. 140, 24-26. 
Clarke, D. B. \& Pedersen, A. K. 1976: Tertiary volcanic province of West Greenland. In Escher, A. \& Watt, W. S. (edit.) Geology of Greenland, 365-385. Copenhagen: Geol. Surv. Greenland.

Escher, A. \& Burri, M. 1967: Stratigraphy and structural development of the Precambrian rocks in the area north-east of Disko Bugt, West Greenland. Rapp. Grønlands geol. Unders. 13, 28 pp.

Garde, A. \& Steenfelt, A. 1989: (this report).

Henderson, G., Rosenkrantz, A. \& Schiener, E. J. 1976: Cretaceous-Tertiary sedimentary rocks of West Greenland. In Escher, A. \& Watt, W. S. (edit.) Geology of Greenland, 341-362. Copenhagen: Geol. Surv. Greenland.

Kalsbeek, F. \& Taylor, P. N. 1986: Chemical and isotopic homogeneity of a $400 \mathrm{~km}$ long basic dyke in central West Greenland. Contr. Miner. Petr. 93, $439-448$.

Kalsbeek, F., Taylor, P. N. \& Pidgeon, R. T. 1988: Unreworked Archaean basement and Proterozoic supracrustal rocks from northeastern Disko Bugt, West Greenland: implications for the nature of Proterozoic mobile belts in Greenland. Can. J. Earth Sci. 25, 773-782.

Knudsen, C., Appel, P. W. U., Hageskov, B. \& Skjernaa, L. 1988: Geological reconnaissance in the Precambrian basement of the Atâ area, central West Greenland. Rapp. Grønlands geol. Unders. 140, 9-17.

Larsen, L. M. \& Pedersen, A. K. 1988: Investigations of Tertiary volcanic rocks along the south coast of Nûgssuaq and in eastern Disko, 1987. Rapp. Grønlands geol. Unders. 140, 28-32.

Larsen, L. M. \& Pedersen, A. K. 1989: New geological investigations in eastern Disko: redeposited volcanoclastic sediments with rhyolite from the Nordfjord Member. Rapp. Grønlands geol. Unders. 145 (this volume).
Marker, M. \& Knudsen, C. 1989: Middle Proterozoic ultramafic lamprophyre dykes in the Archaean of the Atâ area, central West Greenland. Rapp. Grønlands geol. Unders. 145 (this report).

Midtgaard, H. \& Olsen, T. 1989: Sedimentological studies in the Upper Cretaceous coal-bearing strata of southern Nûgssuaq, central West Greenland. Rapp. Grønlands geol. Unders. 145 (this volume).

Pedersen, G. K. \& Jeppesen, M. W. 1988: Examples of bar accretion in fluvial sand, the Atane Formation, eastern Disko, West Greenland. Rapp. Grønlands geol. Unders. 140, 38-43.

Pedersen, G. K. \& Rasmussen, B. F. 1989: New observations of marine trace fossils in delta plain sequences, southern Nûgssuaq, West Greenland. Rapp. Grønlands geol. Unders. 145 (this volume).

Pulvertaft, T. C. R. 1989: Reinvestigation of the Cretaceous boundary fault in Sarqaqdalen, Nûgssuaq, central West Greenland. Rapp. Gronlands geol. Unders. 145 (this volume).

Steenfelt, A. 1987: Gold in the fine fraction of stream sediments from supracrustal sequences in West Greenland. Unpubl. intern. GGU rep., 10 pp.

Steenfelt, A. 1988: Progress in geochemical mapping of West Greenland. Rapp. Grønlands geol. Unders. 140, 17-24.

Thorning, L. 1989: (this volume).

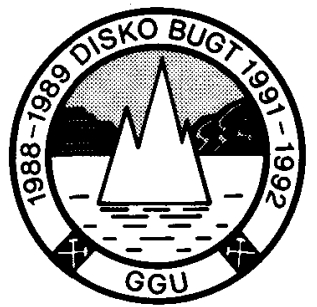

As part of the GGU activity in the Disko Bugt region, central West Greenland (Kalsbeek, 1989), the authors carried out helicopter-supported geological reconnaissance mapping and stream sediment sampling for geochemical mapping in the area between Jakobshavn Isfjord and Qarajaq Isfjord (fig. 1). A considerable part of the season was spent in the eastern part of the Nûgssuaq peninsula, partly to complete the stream sediment sampling initiated in 1986 (see Steenfelt, 1988) and also because previous geological field work in eastern Nûgssuaq was very limited. The existing geological map at a scale of 1:500 000 covering Nûgssuaq is almost entirely based on interpretation of aerial photographs.

During the field work large occurrences of hitherto unknown anorthosite/gabbro rocks and supracrustal sequences were discovered in the gneiss terrain. Both the anorthosite/gabbro and supracrustal units appear to be tectonically interleaved with strongly foliated, flat-lying or shallowly south-dipping orthogneisses, which themselves contain numerous shear zones suggesting substantial subhorizontal movements. 